【方法】脳ファントムを使用し、TCTによる補正画像と従来の SPECT画像との比較を行った。また実際に健常者の頭部を撮像し 被曝についても検討を行った。

【まとめ】今回購入TCTキットは操作性も良く、短時間で必要なとき 即準備が可能であり，臨床において即応性があると思われた。 た，良好なミュウマップの作成が可能であり，SPECT画像の定量 性の精度向上や，SPECT画像とTCT画像の重ね合わせなどによ り，今後TIやGa等の腫瘍SPECT異常集積部位の解剖学的位置確認 も可能であり，機能的診断の精度向上のみならず形態学的診断精度 の向上にも期待されるものと思われた．しかし，今回の試みが一般 に普及するには、法律上の問題が残されており一刻も早い法の改正 が望まれる。

\section{6 血清ペプシノゲンのカットオフ值の検討}

日本鐝管病院松枝由美，他 2 名

【目的】現在, 血清ペプシノゲン $(P G)$ は血清学的胃癌スクリーニン グ法として健診等に用いられているが，施設によって用いられてい るカットオフ值が異なり，若年者の陽性率が低い，年齢が高くなる につれ，偽陽性も高くなるなどの問題点が指摘されている。そこで 最適なカットオフ值を検討した。

【対象】胃癌 294例、非癌患者 904例

【使用キット】ダイナボット社 ベプシノゲンリ・リアビーズおよび ペプシノゲンII・リアビース

【結果】PGは年齢と関係があると言われているが、非癌患者におい てPGI，IIは年齢と無関係、1/11比は年踰とともに低下する傾向を認 めた。 従来のPG $\mathrm{I}<70 \mathrm{ng} / \mathrm{ml}$ か $\mathrm{l} / \mathrm{II}$ 比<3.0は30 40歳代の胃癌陽 性率が低いので, PG II $>17 \mathrm{ng} / \mathrm{ml}$ かつ $/ 111$ 比<2.5を用いたところ， 若年者から高齢者までの胃癌陽性率が向上した。なお，最適なカッ トオフ值をさらに検討中である。

CT

$$
\text { 座長 埼玉医科大学総合医療センター 島田 } 15
$$

\section{7 急性虫垂焱におけるガストログラフィン注腸CTの有用性 の検討}

聖マリアンナ医科大学横浜市西部病院 立石賮代子，他 7名 【目的】成人の急性虫垂炎は，臨床所見，単純撮影，超音波で診断困 難とされる症例を経験することもよくある．そこで今回，希釈した ガストログラフィンを透視下で注腸後，骨盤腔CT検査を行い，そ の有用性について検討したので報告する。

【方法】急性虫垂炎が疑われ，従来の検查では診断が難しい症例に対 し，3\%のガストログラフィンを透視下で回盲部まで逆行性に注入 し，骨盤腔CT検査を行い検討した。

【結果および考察】従来の透視下ガストログラフィン注腸では原液を 使用するので使用量に制限があり，回盲部周辺の精査は難しかっ た。そこで，希积したガストログラフィンを回盲部まで送りCT検 查を行うことで，虫垂だけでなく骨盤腔全体を観察することができ た。一般に回盲部は，内視鏡，注腸造影が難しいと言われている部 位なので，今後は他の回盲部疾患の適応についても検討していきた いと思う。

\section{8 側弯症のCTにおける検討}

信州大学医学部附属病院 安藤 隆, 他 3 名

【目的】側弯症のCTに関しては脊柱骨が湾曲しているため，通常の スキャン方法では椎体が斜めにスキャンされ，正しいアキシャル像 が得られない，これらを改善する万法について検討する。

【方法】被検者を側卧位に寝かせ，スキャン範囲の背中が垂直になる ようにし、脊柱がベッド長軸方向に平行に，ポジショニングを行い $90^{\circ}$ 方向のスキャノグラムを撮影し，正面像のスキャノグラムを得 る. それに対してガントリ角を調整することによりアキシャル像を 得る.また，通常の体位でへリカルスキャンを行い，その画像をリ フォマット姏理を行いアキシャル像を得た。

【結果】上記の方法でいずれも，左右の歪みの改善されたアキシャル 像が得られた。

【結論】側臥位法はリフォマット法に比べ，脊柱の湾曲，捻れに対し て十分ではないが，画像が良い、スキャノグラム上の位置が明確で ある，処理時間が少ないので実用的であった。

\section{9 非イオン性造影郕におけるCT值の経時的变化の検討} 山梨医科大学医学部附属病院 相川良人，他门口名 【目的】非イオン性造影剤の化学・物理的性質はそれぞれの種類によ
り異なる、そのため，各種非イオン性造影刜の種類により，経時的 に血管と実質臟器の造影差が生じる. 今回 5 種類の非イオン性造 影剤について，至適撮影タイミングの指摽となるように，血管と実 質臓器の経時的CT値の変化について検討した。

【対象および方法】対象は、イオヘキンール 300，イオパミドール 300、イオベルソル 320，イオメプロール300および350について 体重当たり $1.5 \mathrm{ml} 30$ 秒間で急速静注後，肝門部にて動脈相(15 45 秒) ·門脈相 $(55 \sim 1$ 分 25 秒 $) \cdot 1$ 分 45 秒 $\cdot 2$ 分 $\cdot 3$ 分 $\cdot 4$ 分 $\cdot 5$ 分と撮影し大動脈・下大静脈・門脈・肝実質・脾実質のCT值のピ 一ク時間, 1/2時間, 画像コントラストについて評価した。

【結果】CT值は、ヨード含有量の多いものほど高くなった。平衡相 (5 分)での肝実質と大動脈・門脈は粘稠度と浸透圧の高い造影剂が 高くなり，粘稠度・浸透圧の低い造影剤が最も低くなった。肝実質 と大動脈・門脈の画像上のコントラストのつく時間は，浸透圧の高 い造影剤が最も遅くなった。

\section{X線検弯 II(CR)}

\section{座長 干葉大学医学部附属病院 梁川範幸}

\section{FCRシステムの現状と将来展望}

富士メディカルシステム(株) 大高幸子

FCR (Fuji computed radiography) は蓄積性蛍光体を用いた初 めてのディジタルX線画像診断装置として，1983年に実用化され た。このシステムではディジタル画像処理技術を活用して，各種の 診断目的に適合したX線画像を安定して提供するのが基本的な考え 方である、ここでは，FCRシステム一画像読取装置、イメージン グプレート(IP)、画像処理一の現状と将来展望について紹介する.

\section{1骨撮影におけるFCR-EDRの検討一第 1 報一}

横浜労災病院 木村文治, 他 5 名

【目的】CR-EDRは，对象部位および，撮影目的によって選択され るものであるが、運用上の利便さから，まずAUTO modeが選択さ れる傾向にある. しかしながら，利便さの一方で，いくつかの問題 点があり，多彩な撮影法を要求される骨撮影では，ルーチン撮影上 支障を来すことがある．そこで，骨撮影における対象部位および撮 影方向でのEDR選択の問題点について検討した。

【方法11)AUTO modeで支障を来した対象部位および撮影方向での 問題点を整理した．2)代表的な撮影部位および撮影方向でのX線強 度プロファイルを測定するとともに，ヒストグラム解析から支障と なった問題点を考察した。

【結果・考察】1)AUTO modeでの問題点は，a)吸収差による読み 取りエラーの発生, b) 画像階調の再現性, の二つに集約できる. 両者共にL值の変動が大きく関わっているが，L値によるX線強度 (線量)およびディジタル值の差からの評価基準を見い出すことがで きた．2)部位および撮影法によるEDRの選択指針が得られるとと もに, FIX modeの有用性を示唆した。

\section{2 骨撮影におけるFCR-EDRの検討一第 2 報一}

横浜労災病院 星 雅彦，他 5 名

【目的】第 1 報では，EDRを部位および撮影方法ごとに選択する有 用性を示唆した。そこで第 2 報では，比較的読み取りエラ一の多 い，X線吸収差の大きい部位を対象に，上值を固定できるEDRの中 から，FIX modeを利用したルーチン化について検討したので報告 する。

【方法】1)FIX modeでS值 200におけるディジタル特性曲線を作成 し，各し值での飽和線量を求めた．2)各電圧での被写体コントラス トカーブを作成し、L值による変化を求めた．3）骨封入ファントム にて視覚評価を行った。4)撮影管電圧とL値の組み合わせによる比 較検討を行った。

【結果・考察】1)FIX modeに設定することでL值が固定され，その 後の階調処理に至る以前の問題点でもある管電圧による被写体コン トラストのコントロールが可能となり，良好な結果を得ることがで きた。2)特に吸収差の大きい撮影部位では、読み取りエラーが皆 無となった。

\section{3 骨撮影における F CR-EDRの検討一第 3 報一}

横浜労災病院 金澤謙太, 他 5 名

【目的】開院当初からこれまでの間，骨撮影は，おもにEDRを AUTO modeを前提とする画像処理パラメータを使用してきた。し かし、第 1 報、第 2 報に示すように、FIX modeを積極的に利用 することにより，L值・S值が固定され，より処理パラメータが安 